\title{
Calibrated automated thrombinography (CAT)
}

Citation for published version (APA):

Hemker, H. C. (2005). Calibrated automated thrombinography (CAT). Thrombosis Research, 115(3), 255. https://doi.org/10.1016/j.thromres.2004.06.042

Document status and date:

Published: 01/01/2005

DOI:

10.1016/j.thromres.2004.06.042

Document Version:

Publisher's PDF, also known as Version of record

\section{Please check the document version of this publication:}

- A submitted manuscript is the version of the article upon submission and before peer-review. There can be important differences between the submitted version and the official published version of record.

People interested in the research are advised to contact the author for the final version of the publication, or visit the DOI to the publisher's website.

- The final author version and the galley proof are versions of the publication after peer review.

- The final published version features the final layout of the paper including the volume, issue and page numbers.

Link to publication

\footnotetext{
General rights rights.

- You may freely distribute the URL identifying the publication in the public portal. please follow below link for the End User Agreement:

www.umlib.nl/taverne-license

Take down policy

If you believe that this document breaches copyright please contact us at:

repository@maastrichtuniversity.nl

providing details and we will investigate your claim.
}

Copyright and moral rights for the publications made accessible in the public portal are retained by the authors and/or other copyright owners and it is a condition of accessing publications that users recognise and abide by the legal requirements associated with these

- Users may download and print one copy of any publication from the public portal for the purpose of private study or research.

- You may not further distribute the material or use it for any profit-making activity or commercial gain

If the publication is distributed under the terms of Article $25 \mathrm{fa}$ of the Dutch Copyright Act, indicated by the "Taverne" license above, 


\section{THROMBOSIS RESEARCH}

ELSEVIER

intl.elsevierhealth.com/journals/thre

\section{Letters-to-the-Editors-in-Chief}

\section{Calibrated automated thrombinography (CAT)}

In their article "Evaluation of a novel kallikrein inhibitor on haemostatic activation in vitro", Tanaka et al. [1] use a technique for measuring thrombin generation by adding a fluorogenic substrate that we developed over the last few years $[2,3]$, on basis of previous work with a chromogenic method [4]. By some regrettable oversight, the references to our work have been omitted. As the technique proves to be useful in a variety of clinical and laboratory situations (control of antithrombotic treatment, estimation of thrombotic and bleeding risk) [5] your readers might want to know where to find the original descriptions. We therefore add the relevant references to this letter.

\section{References}

[1] Tanaka KA, Szlam F, Katori N, Vega JD, Levy JH. Evaluation of a novel kallikrein inhibitor on hemostatic activation in vitro. Thromb Res 2004;113:333-9.
[2] Hemker HC, Giesen PL, Ramjee M, Wagenvoord R, Beguin S. The thrombogram: monitoring thrombin generation in platelet-rich plasma. Thromb Haemost 2000;83:589-91.

[3] Hemker HC, Giesen P, AlDieri R, Regnault V, de Smed E, Wagenvoord R, et al. The calibrated automated thrombogram (CAT): a universal routine test for hyper- and hypocoagulability. Pathophysiol Haemost Thromb 2002; $32: 249-53$.

[4] Hemker HC, Wielders S, Kessels H, Beguin S. Continuous registration of thrombin generation in plasma, its use for the determination of the thrombin potential. Thromb Haemost 1993;70:617-24.

[5] Hemker HC, Beguin S. Phenotyping the clotting system. Thromb Haemost 2000;84:747-51.

H.C. Hemker

Synapse BV, Cardiovascular Research Institute Maastricht, University of Maastricht, P.O. Box 616, 6200, Maastricht, Netherlands E-mail address: hc.hemker@thrombin.com. Tel.: +31 43388 1675; fax: +31433670916.

Received 24 June 2004 